\title{
State of methylation and epigenome studies in some types of head and neck cancer.
}

\author{
Bonar-Alvarez $\mathbf{P}^{1}$, Perez-Sayans $\mathbf{M}^{1^{*}}$, Padín-Iruegas $\mathbf{E}^{2}$, Suarez-Penaranda $\mathrm{JM}^{3}$, Oliveira- Alves $\mathbf{M}^{4}$, \\ Blanco Carrion $\mathbf{A}^{\mathbf{1}}$, García-Garcia $\mathrm{A}^{\mathbf{1}}$ \\ ${ }^{1}$ Oral Medicine, Oral Surgery and Implantology Unit, Santiago de Compostela, Spain \\ ${ }^{2}$ Human Anatomy and Embryology Area, Department of Functional Biology and Health Sciences, Pontevedra, Spain \\ ${ }^{3}$ Pathology and Anatomy Unit, Hospital Clinico Universitario de Santiago, Choupana s/n Santiago de Compostela, \\ Spain \\ ${ }^{4}$ Faculdade de Odontologia de São José dos Campos, Universidade Estadual Paulista "Júlio de Mesquita Filho", Brazil
}

\begin{abstract}
Oral Squamous Cell Carcinomas (OSCC) are one of the most frequent cancers in the world. This term is used to describe malignant tumors of the oral cavity, pharynx and larynx, with a high incidence and mortality. Deregulation of genetic expression is a common process; however, to this we must also add epigenetic modifications, which consist of histone changes, altered expression of miRNAs and aberrant DNA methylation. The main purpose of this study is to review the methylation promoter genes in OSCC and to determine the degree of methylation in these types of tumors, in addition to analyzing the latest studies on the usefulness of these genes as epigenetic markers for early detection and to determine the recurrence of the disease and offer new treatment options.
\end{abstract}

Keywords: Epigenetics, Methylation, Oral squamous cell carcinoma (OSCC), Panel of biomarkers, Oral cancer. Accepted on July 4, 2018

\section{Introduction}

The head and neck cancer included Oral Squamous Cell Carcinoma (OSCC) which accounts for $90 \%$ of all head and neck cancers and $3 \%-4 \%$ of malignancies [1,2]. The incidence of head and neck cancer has increased significantly in the last 20 years. The most important risk factors are smoking and alcohol consumption, and environmental exposure, there are also other risk factors such as the Epstein-Barr virus, the human papilloma virus, subtypes 16 and 18, deficiencies or disequilibrium in vitamins and micronutrients, like folic acid, vitamins $\mathrm{A}, \mathrm{C}$ and $\mathrm{E}$, zinc and selenium [3].

Carcinogenesis is a multi-step process, in some cases, several epigenetic and genetic alterations accumulate progressively $[4,5]$. Silencing of tumor suppressor genes is associated with for the development of cancer, therefore there are several epigenetic mechanisms that produce this: post-translational modifications of histones, mainly phosphorylation, deacetylation changes and in the ubiquitinylation status $[6,7]$. Eventhought the most studied epigenetic change in DNA is cytosine methylation in $\mathrm{CpG}$ dinucleotide areas.

Methylation occurs in certain regions of tumor suppressor genes, called promoters, which contain a high density of cytosine nucleotides, known as $\mathrm{CpG}$ islands. Methylation is the addition of a methyl group $\left(\mathrm{CH}_{3}\right)$ in carbon 5 of cytosine nitrogenous bases (C) located at $5^{\prime}$ of guanines $(\mathrm{G})$. The presence of aberrant methylation in the gene promoter region is related to gene expression [8-11]. The methyl group is added to cytosine nucleotides through DNA methyltransferase, thereby inhibiting the expression of this type of gene. Methylated genes are responsible cell growth and DNA repair [12]. There are three types of DNA-methyltransferase (DNMTs): DNMT1, which maintains methylation patterns of DNA replication, and DNMT3A and DNMT3B, which are responsible for unmethylated CpGs5 islands [11].

There are approximately 45,000 CpG islands, about 500 base pairs, which are underrepresented regions in the genome, furthermore, they are not distributed casually throughout the genome, appearing more frequently in the promotion of regions and the first axons of specific genes $[13,14]$.

DNA methylation can be used as a indicator for changes which help in the early diagnosis as well as for classification, prognosis and treatment of cancer. The gene promoters methylation profile is different for each tumor type, enabling identification of patterns of tumor specific methylation [15]. The most frequently methylation and silenced genes in cancer cells reside in chromosomal regions showing loss of heterozygosity [16]. 
Several factors could trigger DNA methylation, radiation, smoking (tobacco), stress, diet, hormones handler (such as estradiol) analogues based, cadmium, arsenic, nickel, reactive oxygen species, and several other chemicals, so it is important minimize them, as they play an important role in cancer development [17-19].

There are already described of genes that are methylated in head and neck carcinomas, such genes serve a variety of cellular processes as we explained below. There are a number of genes that are methylated in head and neck carcinomas, such genes serve a variety of cellular processes as explained below. Numerous articles have offered insight on epigenetics, this review seeks to cover all the research regarding DNA methylation in oral cancer, as may be appreciated in Tables $1-3$, which assesses the methylation percentage appearing in OSCC. We will concentrate on a detailed discussion of the genes that are hypermethylated in higher frequency, namely: p16INK4A, p15INK4B, p53, APC, E-cadherin, MGMT, MLH1, $D A P K 1, R A S S F 1 A, R A R \beta$. These genes serve a variety of cellular processes as we explain below [20-23]. Perhaps all these differences in percentages of methylation could be due to the differences between the populations and the different etiological factors.

\section{p16/CDKN2/INK4A}

P16 is located on chromosome 9p21, it inhibits cell cycle arrest of cyclin-dependent kinases 4 and 6 and is vital for the maintenance of the retinoblastoma protein in its active dephosphorylated state. The incidence of methylation ranges from $23 \%$ to $76 \%$ [24-30]. Its epigenetic silencing is related to oral pre-cancer and cancer, and its inactivation is believed to be an early and progressive event in tumor advancement and the degree of dysplasia of premalignant lesions. Kato et al. detected $72.73 \%$ methylation in healthy pretumoral tissue samples, showing that this may be an early event in carcinogenesis and could be useful as a prognostic and diagnostic marker [30]. The p16INK4A methylation is associated with an increase in tumor size, more advanced stages (stages III and IV), lymph node metastasis, increased risk of disease recurrence and a poor prognosis [31-33].

Analyzing the methylation percentages of the different authors we see a great variability in the incidence of methylation, possibly due to the type of sample used and the location or origin thereof (oral cavity, oropharynx, indistinctly). In this case, the low percentages of methylation as they appear in the article of Sanchez-cespedes with $27 \%$ have been obtained in samples of tumors of surgical resection of the head and neck [34]; on the other hand, the highest percentage found was in the article of Kulkarni et al. [25] with $67 \%$, performed in oral squamous cell carcinoma samples. We continue to analyse and see intermediate methylation percentages, such as that found by Calmon et al. [35] with $63 \%$ in 43 samples of head and neck tumors and in parallel Supic et al. [36] with 58\% in samples of oral squamous cell carcinoma tumors. The lowest percentage of methylation was contributed by the Schutter study [37] with $5 \%$ performed on head and neck tumor samples, but with the particularity that they had already been treated with radiotherapy, that's why it's so low. Once all the material and methods of the reviewed works were analysed, we have not found an explanation for the methylation variability in p16 (Table 1 shows a summary of studies analyzing epigentic alterations in $P 16$ ).

\section{P15/CDKN1A/INK4B}

The cyclin-dependent kinase inhibitor is located in a region on chromosome 9p21 [38]. It acts by inhibiting cell growth by preventing cell cycle progression during the G1 phase. Methylation percentage ranges between $9 \%$ and $23 \%$ $[24,28,39,40]$. Takeshima et al. found that healthy and adjacent non-tumor tissues typically exhibit signals of p15INK4B methylation [41] but, Yeh et al. in their study found that $9 \%-28 \%$ of the oral carcinoma squamous cells tissues exhibit methylation of gene $p 15$ [42]. Silencing of $p 16$ and $p 15$ genes due to promoter methylation was found in epithelial malignancies, being present in head and neck carcinoma [43].

\section{$P 53$}

Gene $p 53$ is located on chromosome $17 \mathrm{p} 13$. By altering the function of $p 53$, the ability of cells to respond to stress or injury is also altered, leading to genome instability. This gene plays a role in DNA repair, cell cycle progression, cell differentiation, and apoptosis, its primary function is to be a genome guardian. This gene is the most frequently mutated, methylation ranges from $25 \%$ to $69 \%$ [44-47].

P53 changes arise from the combination of exposure to tobacco and alcohol [48].

\section{APC (Adenomatous polyposis coli)}

This tumor suppressor gene inhibits cell proliferation indirectly through Wnt-1, epigenetic silencing occurs in the early stages of carcinogenesis, which causes an increase in $\beta$-catenin gene and thus increased cell proliferation during carcinogenesis $[49,50]$.

Uesugi et al. detected methylation of $15 \%$ in head and neck carcinoma, and Gao et al. found it in $25 \%$ of the cell lines [50,51]. On the other hand, Fan et al. [52] and Supic et al. [23] do not talk about methylation percentages, they simply described promoter methylation.

\section{E-cadherin/CDH1}

$C D H 1$ gene is located on chromosome 16q22.1 and encodes $E$ cadherin that is involved in maintenance of the epithelial phenotype and regulates tumor invasion [53,54]. The loss of its expression and methylation was observed in the primary tumors of the tongue $[55,56]$. Methylation of this promoter is associated with the performance of invasive tumors and poor prognosis. Methylation frequency ranges from $13 \%$ to $85 \%$ $[23,55]$. 


\section{MGMT (O-6 methylguanine-DNA methyltransferase)}

Located at chromosome 10q26, it encodes MGMT, a DNA repair enzyme which removes adducts caused by alkylating agents; this gene repairs the genome where it undergoes alkylation damage, since it is capable of removing, it can remove alkyl groups that are located at position $\mathrm{O} 6$ of guanine $[25,30]$.

Methylation frequency ranges between $12 \%$ and $74 \%$ according to the different authors shown on the table, contrasting with $9 \%$, which is found in the oral mucosa of healthy individuals [30,57]. These differences in the percentage of methylation could be due to different methodological aspects of the study, so we will focus on the studies in the table to see if we find any difference. Analyzing the lowest percentage found by Rosas et al. [58] with $23 \%$ in samples of head and neck tumors, followed by Righini [39] with $29 \%$ and Sanchez-Cespedes [34] with 33\% in samples of head and neck tumors, in comparison with other authors who find a higher level of methylation but already in samples of oral squamous cell carcinoma tumors, such as Kulkarni et al. [25] with $52 \%$ and Kato et al. [30] with $56 \%$ followed by Kordi-Tamandani [59] with $74 \%$, so we could deduce that oral cavity tumors have higher MGMT methylation than head and neck tumors, possibly because they have the first contact with carcinogens and therefore they present different exposure than tumors of the head and neck. The silencing occurs early in carcinogenesis [30] and is associated with advanced disease, lymph node metastasis, poor prognosis and low patient survival [30,57]. (Table 1 shows a summary of studies analyzing epigentic alterations in P16 and MGMT).

\section{MLH1 (MutL homolog 1)}

Located in the region of chromosome 3 p21.3, it is thought that methylation of the 5' region promoter can silence the expression of $M L H 1$ genes and thus downregulates protein expression.

MLH1 methylation may be associated with a higher risk of developing oral malignancies [60]. In a recent study, Gonzalez et al. found promoter hMLH1 methylated in $38(76 \%)$ patients with OSCC, but in none of the control samples; the study also suggests that promoter methylation is an early cancer event [61]. Methylation percentage ranges from $0 \%$ to $50 \%$, as shown in the Table 3. There is great variability in the methylation of this gene, authors such as Ogi et al. [28] analyzing 96 tumors of tongue, gum and floor of mouth (oral squamous cell carcinoma) do not find methylation of this gene; and Viswanathan [62] found $8 \%$ in oral squamous cell carcinoma; However, Puri et al. [63], analyses 51 samples of head and neck tumors and $23 \%$ of them show methylation, likewise in higher percentages, Liu et al. [64] in his study he has $88 \%$ methylation in head and neck cancer. In contrast to the MGMT gene, we see that the location of the head and neck is more methylated than the oral ones.

\section{DAPK1 (Death-associated protein kinase 1)}

It is located on chromosome $9 \mathrm{q} 34.1$ and has a proapoptotic effect $[14,25,30]$. DAPK1 methylation frequency ranges from $18 \%$ to $81 \%$, as shown in Table 2 . Analyzing the different percentages of methylation shown in Table 2, we see a lot of variability, so we have been reviewing the material and method of some studies. Regarding Ogi et al. [28] with 7\% analyse tumor samples of oral squamous cell carcinoma (specifically of tongue, lower gum and floor of mouth); the following methylation values would be $11 \%$ and $18 \%$ found by Schutter et al. [37] and Sanchez-Cespedes [34], respectively, being always samples of head and neck tumors and also coinciding with advanced stages; likewise Rosas et al. [58] found 33\% in samples of head and neck tumors. Following high levels of methylation it is important to note $68 \%$ of Kulkarni et al. [25] in samples of oral squamous cell carcinoma tumors (buccal mucosa, tongue, bocaa floor and trigonoretromolar) and coinciding with advanced stadiums; on the other hand Calmon et al. [35] with $81 \%$ in samples of head and neck tumors and all cases presented advanced stages; so these differences instead of focusing on the location of the tumor, would be oriented as to the stage of the tumor, since we see that all studies with a higher percentage of methylation coincide with advanced tumor stages T3-T4. It is a positive mediator of programmed cell death induced by gamma-interferon, which has been used as a tumor marker [22]. Supic et al. found an association between lymph node involvement and an advanced stage of the disease with methylation of this gene [22].

\section{RASSF1A}

Located at $3 \mathrm{p} 21.3$, it shows $7.5 \%$ methylation in head and neck cancer [65]. The methylation of this gene is associated with invasive tumors, and a shorter survival [66]. Methylation frequency ranges between $0 \%$ and $8 \%$ [29] (Table 2 shows a summary of studies analyzing epigenetic alterations in $D A P K$ and $R A S S F-1$ ). The lowest percentage of methylation found in the articles reviewed was that provided by Wong et al. [67] with 5\% in samples of nasopharyngeal tumors; Then Hasegawa et al. [65] in his study found a 7.5\% methylation in samples of head and neck tumors; on the other hand, we have found high levels of methylation of said gene, specifically in the study by Huang et al. [68] with $22.4 \%$ and samples of oral location (oral squamous cell carcinoma) as well as Maruya et al. [29] with $26 \%$ in oral cavity samples (squamous cell carcinoma). Therefore, after analyzing all the methylation percentages, there is a greater methylation of this gene in oral squamous cell carcinoma than in head and neck cancer. The percentage shown by de Shutter et al. (2.4\%) [37], would be in carcinomas of the head and neck after receiving treatment with Radiotherapy, hence the low levels of methylation.

\section{$\boldsymbol{R A R B 2}$}

The $R A R B 2$ gene is a tumor suppressor gene that belongs to the RARB family, located at chromosome $9 \mathrm{q} 34$. It is methylated in cancer. The percentage of methylation of this gene is around $(67 \%)$ [69]. It is closely related the increasing age of patients, 
tumor aggressiveness and poor prognosis [70]. Regarding the studies reviewed, we found that in the study by Worsham et al. [71] we found an $80 \%$ methylation in carcinomas of the nasopharynx and on the other hand Lee et al. [70] $46 \%$ methylation in salivary gland tumors; Youssef et al. [69] $66 \%$ in head and neck cancer; on the other hand Shaw et al. [49] with $73 \%$ methylation mainly in patients with oral squamous cell tumors versus Maruya et al. [29] where the $63 \%$ were samples of head and neck tumors, so we have not found where to explain the differences in methylation levels but if we focus only on the percentages we see that both locations (oral and head and neck) present high levels of methylation. (Table 3 shows a summary of studies analyzing epigentic alterations in Rarb2).

\section{Methylation detection}

Several studies have assessed the presence of methylation in bodily fluids. The ability to determine methylation states in primary tumors, using saliva and serum, could offer the possibility of creating methylation genes panels to detect cancer $[34,58,72]$.

\section{Serum}

Analysis of serum of patients with HNSCC is a promising approach because it is less invasive and can present an effective method to monitor patients.

In the University Johns Hopkins issued the first report on the state of methylation of DNA samples in serum and its relation to head and neck tumors [34]. Blood contains fragments of extracellular DNA that could reveal multiple malignant conditions [73]. Hong Kong, managed to find DAPK promoter methylation in peripheral blood in a study, where 8 patients of $24(33 \%)$ had nasopharyngeal cancer with methylation [67].

The following genes were found in plasma samples of patients with nasopharynx carcinoma: $C D H 1, C D K N 2 B / \mathrm{p} 15$, $C D K N 2 A / p 16$ and $D A P K$, which confirms that the detection of methylation genes in serum is valid for early detection of locoregional recurrence [67]. Sanchez-Cespedes et al. state that, if DNA changes are detected in serum, once the tumor is resectioned, such changes could be indicators of high risk of local recurrence or metastasis in cancer patients [34].

DNA methylation in serum was detected more frequently in patients who developed distant metastases. Therefore, it could be an indicator of recurrence or metastasis [34].

\section{Saliva}

Multiple studies have assessed and detected the presence of promoter methylation after salivary rinses $[39,58,74,75]$. It is a promising biomarker for monitoring and early detection of recurrence [39].

Lopez et al. assessed the efficacy of gene methylation in oral rinses. They observed methylation of $p 16, p 14$ and MGMT in $44 \%, 12 \%$ and $56 \%$ of oral samples, respectively [76].
In the clinical trial developed by Sanchez-Cespedes et al. they studied the methylation patterns of promoter p16, MGMT, $D A P-K$ in head and neck tumors in saliva and were found to be methylation in all stages and, even more so, in the oral cavity. Therefore, this trial allows sensitive detection of DNA in saliva and is useful for monitoring recurrence in patients with head and neck cancers. After resection of the primary tumor, detection of DNA alterations in the serum may be an indicator of a high risk of local or distant recurrence in patients with cancer [34].

\section{Urine}

Currently, there is no gene methylation detection data in the urine of patients with head and neck cancer. Su et al. found DNA fragments in tumor patients with colorectal cancer and detection was easy [77].

\section{Exfoliative cytology}

It is minimally invasive and the brush's use allows for the collection of all epithelial cells [78]. Longo et al. showed after brushing the intraoral mucosa they were able to detect methylation of genes, specifically in a study of 96 patients with oral squamous cell carcinoma where they found the following methylation percentages CCNA1 (60.4\%), DCC (54.2\%) and TIMP3 (35.4\%) [78].

\section{Tissue samples}

The samples are usually taken from precancerous lesions, tumor lesions and/or healthy peritumoral tissue.

Tan et al. proposed that the presence of methylation promoters of the surgical margins of oral squamous cell carcinoma may predict local recurrence [79].

The presence of $D A P K$ promoter methylation detected in histologically negative surgical in patients with oral squamous cell carcinoma was significantly associated with decreased overall survival, thus showing the possibility of using this promoter for prognosis [80].

\section{Correlation of methylation with progression and malignization}

Methylation status in head and neck oral carcinoma has great potential for early detection, monitoring and treatment. There is a correlation between methylation and the severity of the disease and metastasis [81-83].

Methylation of $D A P K$ promoter correlates with advanced stage and presence of metastases [28,34]. Sanchez-Cespedes et al. found in their study that MGMT and DAP-kinase gene promoters were the most frequently methylated in tumors of the oropharynx, DAP-kinase was associated with advanced staging and lymph node metastasis, namely 15 patients $(93 \%)$ with gene methylation had lymph node involvement at the time of diagnosis, representing an important role in tumor dissemination. 
The relationship between methylation of $h M L H 1$ and clinical stages has not been identified yet. However, Tzao et al. described the relationship between methylation and suppression of $h M L H 1$ expression in early stages of esophageal cancer, suggesting that loss of hMLH1 protein methylation occurs at early stages of carcinogenesis [84]. Likewise, Ramirez in his study reaffirms that the methylation of the hMLH1 promoter is an early event that occurs in oral cancer, specifically and ratifies it in a case-control study, in 50 Mexican population patients and 200 control samples. of healthy individuals, found that the methylation promoter of hMLH1 was methylated in $38(76 \%)$ patients with COC; the study showed a high frequency of methylation cases with negative expression for the hMLH1 protein corresponding to an early COCE clinic [85]. Epigenetic silencing of p16 and $p 15$ plays an important role in the early development of head and neck cancer and correlates with poor prognosis [86,87].

We can use $p 16$ as a low biomarker survival and metastasis biomarker $[21,88]$.
Silencing of gene RASSF1A is associated with aggressive tumors and poor survival [66].

Methylation of $M G M T$ is high in cases of mucosa dysplasia, which occurs in the early stages of carcinogenesis [57]. Kordi et al. and Taioli et al. showed that MGMT methylation could be considered as a marker of poor survival of head and neck cancer $[59,89,90]$.

Sanchez-Cespedes et al. and $\mathrm{Ha}$ et al. demonstrated that proteins that control apoptosis such as DAPK and E-cadherin may increase the likelihood of metastasis, as well as an important role in cancer prognosis [14,34], methylation of Ecadherin has its main action on cancer prognosis [22,55,65]. Interestingly, for head and neck cancer, a correlation has been reported between methylation of DAPK and the presence of metastatic lymph nodes [34].

The epigenetic silencing of the MGMT, p16INK4A and DAPK genes involves alterations in the DNA repair process, the cell cycle and the processes related to metastasis, respectively [14].

Table 1. Summary studies analyzing epigenetic alterations in P16 and MGMT.

\begin{tabular}{|c|c|c|c|c|c|c|c|}
\hline Gene & Reference & $\begin{array}{l}\text { Number } \\
\text { cases }\end{array}$ & of Methylation (\%) & Gene & Reference & $\begin{array}{l}\text { Number } \\
\text { cases }\end{array}$ & of Methylation (\%) \\
\hline \multirow{21}{*}{ p16 } & Merlo et al. [91] & ND & ND & \multirow{21}{*}{$M G M T$} & $\begin{array}{l}\text { Sánchez-Cespedes et al. } \\
{[34]}\end{array}$ & 95 & $33 \%$ \\
\hline & Naggar et al. [92] & ND & ND & & Rosas et al. [58] & 30 & $23 \%$ \\
\hline & $\begin{array}{l}\text { Sánchez-Cespedes et } \\
\text { al. [34] }\end{array}$ & 95 & $27 \%$ & & Viswanathan et al. [24] & 99 & $41 \%$ \\
\hline & Nakahara et al. [27] & 32 & $50 \%$ & & & & \\
\hline & Hibi et al. [93] & 31 & $23 \%$ & & Maruya et al. [29] & 32 & $37 \%$ \\
\hline & Esteller et al. [94] & ND & ND & & Kulkarni et al. [25] & 60 & $52 \%$ \\
\hline & Rosas et al. [58] & 30 & $47 \%$ & & Zuo et al. [95] & 94 & $18.10 \%$ \\
\hline & Huang et al. [26] & 48 & $42 \%$ & & Ishida et al. [32] & 49 & $12 \%$ \\
\hline & Ogi et al. [28] & 96 & $29 \%$ & & \multirow{2}{*}{ Puri et al. [96] } & \multirow{2}{*}{62} & \multirow{2}{*}{$30 \%$} \\
\hline & Hasegawa et al. [65] & 80 & $32 \%$ & & & & \\
\hline & Lopez et al. [97] & ND & $44 \%$ & & \multirow{2}{*}{ Kato et al. [30] } & \multirow{2}{*}{55} & \multirow{2}{*}{$56 \%$} \\
\hline & Viswanathan et al. [24] & 99 & $23 \%$ & & & & \\
\hline & Ai L et al. [98] & 100 & $27 \%$ & & Worsham et al. [99] & ND & $20 \%$ \\
\hline & Kulkarni et al. [25] & 60 & $67 \%$ & & Righini et al. [39] & 90 & $29 \%$ \\
\hline & \multirow{2}{*}{ Maruya et al. [29] } & \multirow{2}{*}{32} & \multirow{2}{*}{$33 \%$} & & Sengupto et al. [40] & 99 & $41 \%$ \\
\hline & & & & & Sawhney et al. [57] & 107 & $52 \%$ \\
\hline & Ishida et al. [32] & 49 & $35 \%$ & & \multirow{3}{*}{ Lee et al. [70] } & \multirow{3}{*}{69} & \multirow{3}{*}{ ND } \\
\hline & Tran et al. [100] & 27 & $63 \%$ & & & & \\
\hline & Puri et al. [96] & 62 & $36 \%$ & & & & \\
\hline & Righini et al. [39] & 90 & $29 \%$ & & \multirow{2}{*}{$\begin{array}{l}\text { Kordi-Tamandani et al. } \\
\text { [59] }\end{array}$} & \multirow{2}{*}{76} & \multirow{2}{*}{$74 \%$} \\
\hline & Calmon et al. [35] & 43 & $63 \%$ & & & & \\
\hline
\end{tabular}




\begin{tabular}{|c|c|c|c|c|c|c|c|}
\hline & Sengupta et al. [40] & 99 & $23 \%$ & & & & \\
\hline & Shaw et al. [90] & 79 & $28 \%$ & & & & \\
\hline & Ohta et al. [101] & 44 & $64 \%$ & & & & \\
\hline & De Shutter et al. [82] & 46 & $5 \%$ & & & & \\
\hline & Taioli et al. [89] & 80 & $11.50 \%$ & & & & \\
\hline & Supic et al. [102] & 77 & $58 \%$ & & & & \\
\hline & Pierini et al. [103] & 97 & $47.40 \%$ & & & & \\
\hline Gene & Reference & $\begin{array}{l}\text { Number } \\
\text { cases }\end{array}$ & of Methylation (\%) & Gene & Reference & $\begin{array}{l}\text { Number } \\
\text { cases }\end{array}$ & of Methylation (\%) \\
\hline \multirow{16}{*}{$D A P K$} & $\begin{array}{l}\text { Sanchez-Cespedes et } \\
\text { al. [34] }\end{array}$ & 92 & $18 \%$ & \multirow{16}{*}{ RASSF-1 } & Hasegawa et al. [65] & 80 & $7.50 \%$ \\
\hline & & & & & Maruya et al. [29] & 32 & $16 \%$ \\
\hline & Rosas et al. [58] & 30 & $33 \%$ & & Wong et al. [67] & 41 & $5 \%$ \\
\hline & \multirow{2}{*}{ Hasegawa et al. [65] } & 80 & $24 \%$ & & \multirow{6}{*}{ Worsham et al. [99] } & \multirow{3}{*}{ ND } & \multirow{3}{*}{$84 \%$} \\
\hline & & 96 & $7 \%$ & & & & \\
\hline & \multicolumn{3}{|l|}{ Ogi et al. [28] } & & & & \\
\hline & Maruya et al. [29] & 32 & $25 \%$ & & & \multirow{3}{*}{69} & \multirow{3}{*}{$35 \%$} \\
\hline & Kulkarni et al. [25] & 60 & $68 \%$ & & & & \\
\hline & Wong et al. [67] & 41 & $42 \%$ & & & & \\
\hline & Worsham et al. [99] & ND & $76 \%$ & & De Shutter et al. [82] & 46 & $2.40 \%$ \\
\hline & Calmon et al. [35] & 43 & $81.30 \%$ & & \multirow{6}{*}{ Huang et al. [68] } & \multirow{6}{*}{482} & \multirow{6}{*}{$22.40 \%$} \\
\hline & Righini et al. [39] & 69 & $27 \%$ & & & & \\
\hline & \multirow[b]{2}{*}{ De shutter et al. [82] } & 46 & $11.40 \%$ & & & & \\
\hline & & 77 & $36.80 \%$ & & & & \\
\hline & Supic et al. [102] & & & & & & \\
\hline & $\begin{array}{l}\text { Radhakrishnan et al. } \\
\text { [104] }\end{array}$ & ND & ND & & & & \\
\hline Gene & Reference & $\begin{array}{l}\text { Number } \\
\text { cases }\end{array}$ & of Methylation (\%) & Gene & Reference & $\begin{array}{l}\text { Number } \\
\text { cases }\end{array}$ & of Methylation (\%) \\
\hline \multirow{8}{*}{ RARB2 } & Youssef et al. [69] & 53 & $66 \%$ & \multirow{8}{*}{ HLM1 } & Ogi et al. [28] & 96 & $0 \%$ \\
\hline & Maruya et al. [29] & 32 & $53 \%$ & & Liu et al. [105] & 13 & $92 \%$ \\
\hline & Shaw et al. [49] & 79 & $73 \%$ & & Viswanathan et al. [24] & 99 & $8 \%$ \\
\hline & Worsham [99] & ND & $80 \%$ & & Liu et al. [106] & 8 & $88 \%$ \\
\hline & Lee et al. [70] & 69 & $46 \%$ & & Puri et al. [96] & 51 & $23 \%$ \\
\hline & $\begin{array}{l}\text { Radhakrishann et al. } \\
\text { [104] }\end{array}$ & ND & ND & & $\begin{array}{l}\text { Gonzalez-Ramirez et al. } \\
\text { [61] }\end{array}$ & 38 & $76 \%$ \\
\hline & & & & & Demokan et al. [107] & 116 & $47 \%$ \\
\hline & & & & & Pierini et al. [103] & 97 & $46.40 \%$ \\
\hline
\end{tabular}


State of methylation and epigenome studies in some types of head and neck cancer

Table 2. Summary studies analyzing epigenetic alterations in DAPK and RASSF-1.

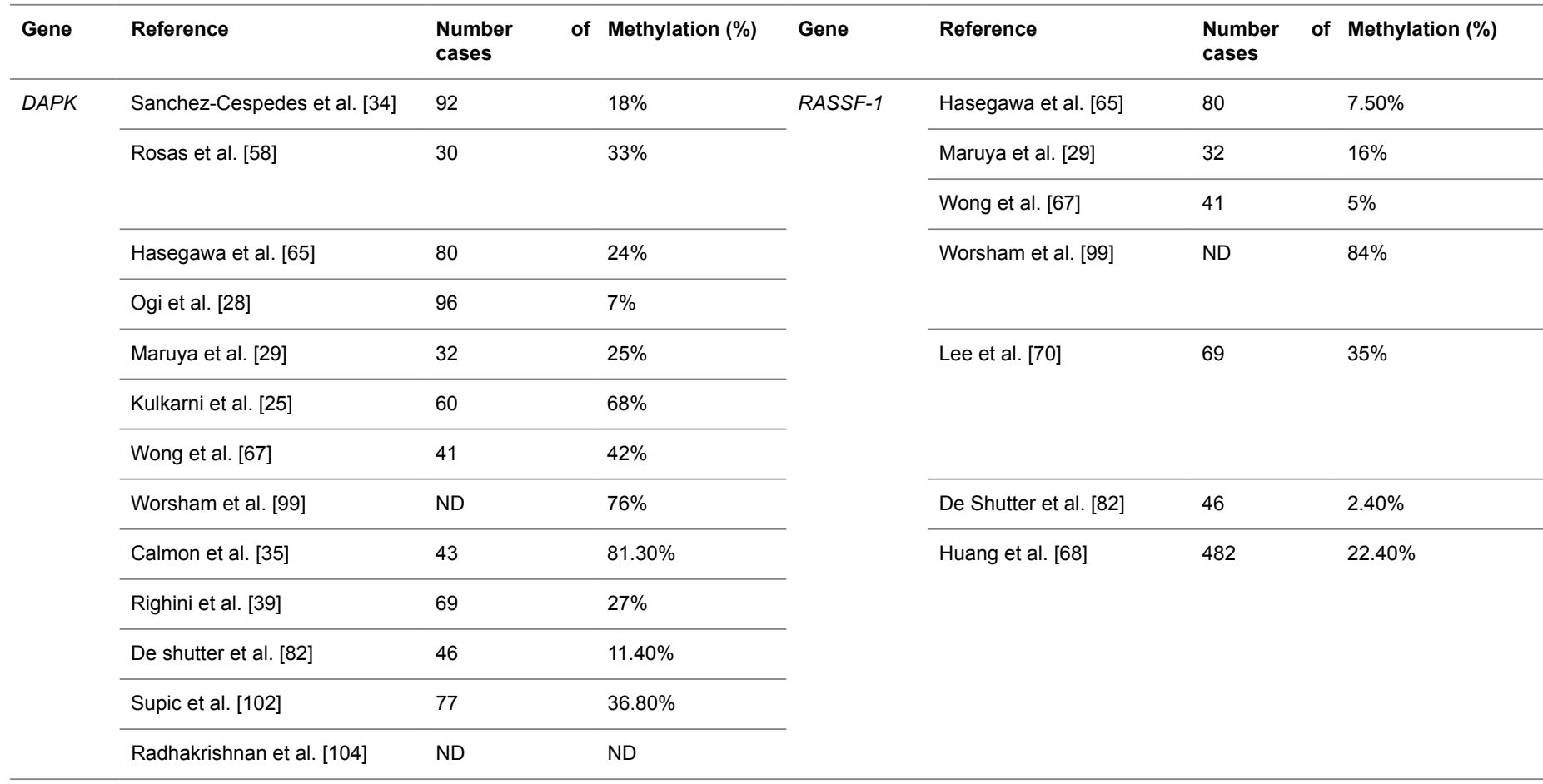

ND: No Data.

Table 3. Summary studies analyzing epigenetic alterations in RARB2 and HLM1.

\begin{tabular}{|c|c|c|c|c|c|c|c|c|}
\hline Gene & Reference & $\begin{array}{l}\text { Number } \\
\text { cases }\end{array}$ & of & Methylation (\%) & Gene & Reference & $\begin{array}{l}\text { Number of } \\
\text { cases }\end{array}$ & Methylation (\%) \\
\hline \multirow[t]{8}{*}{ RARB2 } & Youssef et al. [69] & 53 & & $66 \%$ & HLM1 & Ogi et al. [28] & 96 & $0 \%$ \\
\hline & Maruya et al. [29] & 32 & & $53 \%$ & & Liu et al. [105] & 13 & $92 \%$ \\
\hline & Shaw et al. [49] & 79 & & $73 \%$ & & Viswanathan et al. [24] & 99 & $8 \%$ \\
\hline & Worsham [99] & ND & & $80 \%$ & & Liu et al. [106] & 8 & $88 \%$ \\
\hline & Lee et al. [70] & 69 & & $46 \%$ & & Puri et al. [96] & 51 & $23 \%$ \\
\hline & Radhakrishann et al. & ND & & ND & & González-Ramirez et al. [61] & 38 & $76 \%$ \\
\hline & & & & & & Demokan et al. [107] & 116 & $47 \%$ \\
\hline & & & & & & Pierini et al. [103] & 97 & $46.40 \%$ \\
\hline
\end{tabular}

ND: No Data.

\section{Conclusions}

Advances in epigenetics have a key role in diagnosing, choosing the treatment, obtaining good prognosis and detecting head and neck carcinomas in primary stages and determining the degree of aggressiveness and predict their evolution. That is why we need a panel of well-established methylation promoters for optimal treatment of these patients and mainly to identify early-stage carcinomas. This review aims to highlight the genes that are methylated most frequently and are associated with poor prognosis and the frequency of metastasis, so we believe that more quantitative studies of the methylation degree of genes MGMT, DAPK, hMLH1 are necessary. Long-term studies in patients with head and neck cancer are necessary, to analyse the methylation percentages once they are cured of the disease, thus obtaining more realistic figures in terms of prognosis, survival of these genes and the production of methylation panels with a higher reliability.

\section{References}

1. Barnes L, Eveson J, Reichart P, Sidransky D. World Health Organization classification of tumours: pathology and genetics of head and neck tumours. WHO 2005.

2. Bagan J, Sarrion G, Jimenez Y. Oral cancer: clinical features. Oral Oncol 2010; 46: 414-417.

3. Eleftheriadou A, Chalastras T, Ferekidou E, Yiotakis I, Kyriou L, Tzagarakis M. Association between squamous 
cell carcinoma of the head and neck and serum folate and homocysteine. Anticancer Res 2006; 26: 2345-2348.

4. Feinberg AP. Cancer epigenetics takes center stage. Proc Natl Acad Sci U S A 2001; 98: 392-394.

5. Tang WY, Ho SM. Epigenetic reprogramming and imprinting in origins of disease. Rev Endocr Metab Disord 2007; 8: 173-182.

6. Bird A. DNA methylation patterns and epigenetic memory. Genes Dev 2002; 16: 6-21.

7. Vaissicre T, Sawan C, Herceg Z. Epigenetic interplay between histone modifications and DNA methylation in gene silencing. Mut Res Rev Mut Res 2008; 659: 40-48.

8. Stein RA. Epigenetics-the link between infectious diseases and cancer. JAMA 2011; 305: 1484-1485.

9. Portela A, Esteller M. Epigenetic modifications and human disease. Nat Biotechnol 2010; 28: 1057-1068.

10. Esteller M. Epigenetic changes in cancer. F1000 Biol Rep 2011; 3: 9.

11. Rodriguez-Paredes M, Esteller M. Cancer epigenetics reaches mainstream oncology. Nat Med 2011; 330-339.

12. Worm J, Guldberg P. DNA methylation: an epigenetic pathway to cancer and a promising target for anticancer therapy. J Oral Pathol Med 2002; 31: 443-449.

13. Larsen F, Gundersen G, Lopez R, Prydz H. CpG islands as gene markers in the human genome. Genomics 1992; 13: 1095-1107.

14. Ha PK, Califano JA. Promoter methylation and inactivation of tumour-suppressor genes in oral squamous-cell carcinoma. Lancet Oncol 2006; 7: 77-82.

15. Esteller M, Corn PG, Baylin SB, Herman JG. A gene hypermethylation profile of human cancer. Cancer Res 2001; 61: 3225-3229.

16. Baylin SB. DNA methylation and gene silencing in cancer. Nat Clin Pract Oncol 2005; 2: 4-11.

17. Chen J, Xu X. Diet, epigenetic, and cancer prevention. Adv Genet 2010; 71: 237-255.

18. Mathers JC, Strathdee G, Relton CL. Induction of epigenetic alterations by dietary and other environmental factors. Adv Genet 2010; 71: 3-39.

19. Ross SA. Evidence for the relationship between diet and cancer. Exp Oncol 2010; 32: 137-142.

20. Shaw R. The epigenetics of oral cancer. Int J Oral Maxillofac Surg 2006; 35: 101-108.

21. Shaw RJ, Hall GL, Woolgar JA, Lowe D, Rogers SN, Field JK. Quantitative methylation analysis of resection margins and lymph nodes in oral squamous cell carcinoma. Br J Oral Maxillofac Surg 2007; 45: 617-622.

22. Supic G, Kozomara R, Brankovic-Magic M, Jovic N, Magic Z. Gene hypermethylation in tumor tissue of advanced oral squamous cell carcinoma patients. Oral Oncol 2009; 45: 1051-1057.

23. Supic G, Jovic N, Kozomara R, Zeljic K, Magic Z. Interaction between the MTHFR C677T polymorphism and alcohol-impact on oral cancer risk and multiple DNA methylation of tumor-related genes. J Dent Res 2011; 90: 65-70.

24. Viswanathan M, Tsuchida N, Shanmugam G. Promoter hypermethylation profile of tumor-associated genes p16, p15, hMLH1, MGMT and E-cadherin in oral squamous cell carcinoma. Int J Cancer 2003; 105: 41-46.

25. Kulkarni V, Saranath D. Concurrent hypermethylation of multiple regulatory genes in chewing tobacco associated oral squamous cell carcinomas and adjacent normal tissues. Oral Oncol 2004; 40: 145-153.

26. Huang MJ, Yeh KT, Shih HC, Wang YF, Lin TH, Chang JY, Shih MC, Chang JG. The correlation between CpG methylation and protein expression of $\mathrm{P} 16$ in oral squamous cell carcinomas. Int $\mathrm{J}$ Mol Med 2002; 10: 551-554.

27. Nakahara Y, Shintani S, Mihara M, Ueyama Y, Matsumura T. High frequency of homozygous deletion and methylation of p16(INK4A) gene in oral squamous cell carcinomas. Cancer Lett 2001; 163: 221-228.

28. Ogi K, Toyota M, Ohe-Toyota M, Tanaka N, Noguchi M, Sonoda T, Kohama G, Tokino T. Aberrant methylation of multiple genes and clinicopathological features in oral squamous cell carcinoma. Clin Cancer Res 2002; 8: 3164-3171.

29. Maruya S, Issa JP, Weber RS, Rosenthal DI, Haviland JC, Lotan R. Differential methylation status of tumorassociated genes in head and neck squamous carcinoma: incidence and potential implications. Clin Cancer Res 2004; 10: 3825-3830.

30. Kato K, Hara A, Kuno T, Mori H, Yamashita T, Toida M. Aberrant promoter hypermethylation of p16 and MGMT genes in oral squamous cell carcinomas and the surrounding normal mucosa. J Cancer Res Clin Oncol 2006; 132: 735-743.

31. Su PF, Huang WL, Wu HT, Wu CH, Liu TY, Kao SY, p16(INK4A) promoter hypermethylation is associated with invasiveness and prognosis of oral squamous cell carcinoma in an age-dependent manner. Oral Oncol 2010; 46: 734-739.

32. Ishida E, Nakamura M, Ikuta M, Shimada K, Matsuyoshi S, Kirita T, Konishi N. Promotor hypermethylation of p14ARF is a key alteration for progression of oral squamous cell carcinoma. Oral Oncol 2005; 41: 614-622.

33. Sailasree R, Abhilash A, Sathyan KM, Nalinakumari KR, Thomas S, Kannan S. Differential roles of p16INK4A and p14ARF genes in prognosis of oral carcinoma. Cancer Epidemiol Biomarkers Prev 2008; 17: 414-420.

34. Sanchez-Cespedes M, Esteller M, Wu L, Nawroz-Danish H, Yoo GH, Koch WM, Jen J, Herman JG, Sidransky D. Gene promoter hypermethylation in tumors and serum of head and neck cancer patients. Cancer Res 2000; 60: 892-895.

35. Calmon MF, Colombo J, Carvalho F, Souza FP, Filho JF, Fukuyama EE. Methylation profile of genes CDKN2A (p14 and p16), DAPK1, CDH1, and ADAM23 in head 
and neck cancer. Cancer Genet Cytogenet 2007; 173: 31-37.

36. Supia G, Kozomara R, Brankovia-Magia M, Jovia N, Magia Z. Gene hypermethylation in tumor tissue of advanced oral squamous cell carcinoma patients. Oral Oncol 2009; 45: 1051-1057.

37. De Schutter H, Geeraerts H, Verbeken E, Nuyts S. Promoter methylation of TIMP3 and CDH1 predicts better outcome in head and neck squamous cell carcinoma treated by radiotherapy only. Oncol Rep 2009; 21: 507-513.

38. Daa T, Kashima K, Kondo Y, Yada N, Suzuki M, Yokoyama S. Aberrant methylation in promoter regions of cyclin-dependent kinase inhibitor genes in adenoid cystic carcinoma of the salivary gland. APMIS 2008; 116: 21-26.

39. Righini CA, de Fraipont F, Timsit JF, Faure C, Brambilla E, Reyt E. Tumor-specific methylation in saliva: a promising biomarker for early detection of head and neck cancer recurrence. Clin Cancer Res 2007; 13: 1179-1185.

40. Sengupta S, Chakrabarti S, Roy A, Panda CK, Roychoudhury $\mathrm{S}$. Inactivation of human mutL homolog 1 and mutS homolog 2 genes in head and neck squamous cell carcinoma tumors and leukoplakia samples by promoter hypermethylation and its relation with microsatellite instability phenotype. Cancer 2007; 109: 703-712.

41. Takeshima M, Saitoh M, Kusano K, Nagayasu H, Kurashige Y, Malsantha $\mathrm{M}$. High frequency of hypermethylation of p14, p15 and p16 in oral precancerous lesions associated with betel-quid chewing in Sri Lanka. J Oral Pathol Med 2008; 37: 475-479.

42. Yeh KT, Chang JG, Lin TH, Wang YF, Tien N, Chang JY, Chen JC, Shih MC. Epigenetic changes of tumor suppressor genes, P15, P16, VHL and P53 in oral cancer. Oncol Rep 2003; 10: 659-663.

43. Gonzalez MV, Pello MF, Lopez-Larrea C, Suarez C, Menendez MJ, Coto E. Deletion and methylation of the tumour suppressor gene p16/CDKN2 in primary head and neck squamous cell carcinoma. J Clin Pathol 1997; 50: 509-512.

44. Levine AJ, Momand J, Finlay CA. The p53 tumour suppressor gene. Nature 1991; 351: 453-456.

45. Boyle JO, Hakim J, Koch W, van der Riet P, Hruban RH, Roa RA, Correo R, Eby YJ, Ruppert JM, Sidransky D. The incidence of p53 mutations increases with progression of head and neck cancer. Cancer Res 1993; 53: 4477-4480.

46. Caamano J, Zhang SY, Rosvold EA, Bauer B, KleinSzanto AJ. p53 alterations in human squamous cell carcinomas and carcinoma cell lines. Am J Pathol 1993; 142: 1131-1139.

47. Baral R, Patnaik S, Das BR. Co-overexpression of p53 and c-myc proteins linked with advanced stages of beteland tobacco-related oral squamous cell carcinomas from eastern India. Eur J Oral Sci 1998; 106: 907-913.
48. Shin DM, Lee JS, Lippman SM, Lee JJ, Tu ZN, Choi G, Heyne K, Shin HJ, Ro JY, Goepfert H, Hong WK, Hittelman WN. p53 expressions: predicting recurrence and second primary tumors in head and neck squamous cell carcinoma. J Natl Cancer Inst 1996; 88: 519-529.

49. Shaw RJ, Liloglou T, Rogers SN, Brown JS, Vaughan ED, Lowe D. Promoter methylation of P16, RAR $\beta$, Ecadherin, cyclin A1 and cytoglobin in oral cancer: quantitative evaluation using pyrosequencing. Br J Cancer 2006; 94: 561-568.

50. Gao S, Eiberg H, Krogdahl A, Liu CJ, Srrensen JA. Cytoplasmic expression of E-cadherin and beta-catenin correlated with $\mathrm{LOH}$ and hypermethylation of the APC gene in oral squamous cell carcinomas. J Oral Pathol Med 2005; 34: 116-119.

51. Uesugi H, Uzawa K, Kawasaki K, Shimada K, Moriya T, Tada A, Shiiba M, Tanzawa H. Status of reduced expression and hypermethylation of the APC tumor suppressor gene in human oral squamous cell carcinoma. Int J Mol Med 2005; 15: 597-602.

52. Fan C. Epigenetic alterations in head and neck cancer: prevalence, clinical significance, and implications. Curr Oncol Rep 2004; 6: 152-161.

53. Takeichi M. Cadherin cell adhesion receptors as a morphogenetic regulator. Science 1991; 251: 1451-1455.

54. Thomas GJ, Speight PM. Cell adhesion molecules and oral cancer. Crit Rev Oral Biol Med 2001; 12: 479-498.

55. Chang HW, Chow V, Lam KY, Wei WI, Wing Yuen AP. Loss of E-cadherin expression resulting from promoter hypermethylation in oral tongue carcinoma and its prognostic significance. Cancer 2002; 94: 386-392.

56. Kudo Y, Kitajima S, Ogawa I, Hiraoka M, Sargolzaei S, Keikhaee MR, Sato S, Miyauchi M, Takata T. Invasion and metastasis of oral cancer cells require methylation of E-cadherin and/or degradation of membranous betacatenin. Clin Cancer Res 2004; 10: 5455-5463.

57. Sawhney M, Rohatgi N, Kaur J, Gupta SD, Deo SV, Shukla NK, Ralhan R. MGMT expression in oral precancerous and cancerous lesions: correlation with progression, nodal metastasis and poor prognosis. Oral Oncol 2007; 43: 515-522.

58. Rosas SL, Koch W, da Costa Carvalho MG, Wu L, Califano J, Westra W. Promoter hypermethylation patterns of p16, O6-methylguanine-DNA-methyltransferase, and death-associated protein kinase in tumors and saliva of head and neck cancer patients. Cancer Res 2001; 61: 939-942.

59. Kordi-Tamandani DM, Moazeni-Roodi A, Rigi-Ladiz M, Hashemi M, Birjandian E, Torkamanzehi A. Promoter hypermethylation and expression profile of MGMT and CDH1 genes in oral cavity cancer. Arch Oral Biol 2010; 55: 809-814.

60. Czerninski R, Krichevsky S, Ashhab Y, Gazit D, Patel V, Ben-Yehuda D. Promoter hypermethylation of mismatch repair genes, hMLH1 and hMSH2 in oral squamous cell carcinoma. Oral Dis 2009; 15: 206-213. 
61. Gonzalez-Ramirez I, Ramirez-Amador V, IrigoyenCamacho M, Sánchez-Pérez Y, Anaya-Saavedra G, Granados-Garcia M. hMLH1 promoter methylation is an early event in oral cancer. Oral Oncol 2011; 47: 22-26.

62. Viswanathan M, Tsuchida N, Shanmugam G. Promoter hypermethylation profile of tumor-associated genes $\mathrm{p} 16$, p15, hMLH1, MGMT and E-cadherin in oral squamous cell carcinoma. Int J Cancer 2003; 105: 41-46.

63. Puri SK, Si L, Fan CY, Hanna E. Aberrant promoter hypermethylation of multiple genes in head and neck squamous cell carcinoma. Am J Otolaryngol 2005; 26: 12-17.

64. Liu K, Zuo C, Luo QK, Suen JY, Hanna E, Fan C. Promoter hypermethylation and inactivation of hMLH1, a DNA mismatch repair gene, in head and neck squamous cell carcinoma. Diagn Mol Pathol 2003; 12: 50-56.

65. Hasegawa M, Nelson HH, Peters E, Ringstrom E, Posner M, Kelsey KT. Patterns of gene promoter methylation in squamous cell cancer of the head and neck. Oncogene 2002; 21: 4231-4236.

66. Lee ES, Issa JP, Roberts DB, Williams MD, Weber RS, Kies MS. Quantitative promoter hypermethylation analysis of cancer-related genes in salivary gland carcinomas: comparison with methylation-specific PCR technique and clinical significance. Clin Cancer Res 2008; 14: 2664-2672.

67. Wong TS, Kwong DL, Sham JS, Wei WI, Kwong YL, Yuen AP. Quantitative plasma hypermethylated DNA markers of undifferentiated nasopharyngeal carcinoma. Clin Cancer Res 2004; 10: 2401-2406.

68. Huang KH, Huang SF, Chen IH, Liao CT, Wang HM, Hsieh LL. Methylation of RASSF1A, RASSF2A, and HIN-1 is associated with poor outcome after radiotherapy, but not surgery, in oral squamous cell carcinoma. Clin Cancer Res 2009; 15: 4174-4180.

69. Youssef EM, Lotan D, Issa JP, Wakasa K, Fan YH, Mao L, Hassan K, Feng L, Lee JJ, Lippman SM, Hong WK, Lotan R. Hypermethylation of the retinoic acid receptorbeta(2) gene in head and neck carcinogenesis. Clin Cancer Res 2004; 10: 1733-1742.

70. Lee ES, Issa JP, Roberts DB, Williams MD, Weber RS, Kies MS. Quantitative promoter hypermethylation analysis of cancer-related genes in salivary gland carcinomas: comparison with methylation-specific PCR technique and clinical significance. Clin Cancer Res 2008; 14: 2664-2672.

71. Worsham MJ, Chen KM, Meduri V, Nygren AO, Errami A, Schouten JP, Benninger MS. Epigenetic events of disease progression in head and neck squamous cell carcinoma. Arch Otolaryngol Head Neck Surg 2006; 132: 668-677.

72. Palmisano WA, Divine KK, Saccomanno G, Gilliland FD, Baylin SB, Herman JG, Belinsky SA. Predicting lung cancer by detecting aberrant promoter methylation in sputum. Cancer Res 2000; 60: 5954-5958.
73. Ziegler A, Zangemeister-Wittke U, Stahel RA. Circulating DNA: a new diagnostic gold mine? Cancer Treat Rev 2002; 28: 255-271.

74. Carvalho AL, Jeronimo C, Kim MM, Henrique R, Zhang $\mathrm{Z}$, Hoque MO. Evaluation of promoter hypermethylation detection in body fluids as a screening/diagnosis tool for head and neck squamous cell carcinoma. Clin Cancer Res 2008; 14: 97-107.

75. Rettori MM, de Carvalho AC, Longo ALB, de Oliveira CZ, Kowalski LP, Carvalho AL. Prognostic significance of TIMP3 hypermethylation in post-treatment salivary rinse from head and neck squamous cell carcinoma patients. Carcinogenesis 2013; 34: 20-27.

76. Lopez M, Aguirre JM, Cuevas N, Anzola M, Videgain J, Aguirregaviria J, Martínez de Pancorbo M. Gene promoter hypermethylation in oral rinses of leukoplakia patients-a diagnostic and/or prognostic tool? Eur J Cancer 2003; 39: 2306-2309.

77. Su Y, Wang M, Brenner DE, $\mathrm{Ng} \mathrm{A}$, Melkonyan $\mathrm{H}$, Umansky S. Human urine contains small, 150 to 250 nucleotide-sized, soluble DNA derived from the circulation and may be useful in the detection of colorectal cancer. J Mol Diagn 2004; 6: 101-107.

78. Longo AL, Rettori MM, de Carvalho AC, Kowalski LP, Carvalho AL, Vettore AL. Evaluation of the methylation profile of exfoliated cell samples from patients with head and neck squamous cell carcinoma. Head Neck 2014; 36: 631-637.

79. Tan H, Saulnier P, Auperin A, Lacroix L, Casiraghi O, Janot F. Quantitative methylation analyses of resection margins predict local recurrences and disease-specific deaths in patients with head and neck squamous cell carcinomas. Br J Cancer 2008; 99: 357-363.

80. Supic G, Kozomara R, Jovic N, Zeljic K, Magic Z. Prognostic significance of tumor-related genes hypermethylation detected in cancer-free surgical margins of oral squamous cell carcinomas. Oral Oncol 2011; 47: 702-708.

81. Poage GM, Christensen BC, Houseman EA, McClean MD, Wiencke JK, Posner MR. Genetic and epigenetic somatic alterations in head and neck squamous cell carcinomas are globally coordinated but not locally targeted. PLoS One 2010; 5: 9651.

82. De Schutter H, Geeraerts H, Verbeken E, Nuyts S. Promoter methylation of TIMP3 and CDH1 predicts better outcome in head and neck squamous cell carcinoma treated by radiotherapy only. Oncol Rep 2009; 21: 507-513.

83. Steinmann K, Sandner A, Schagdarsurengin U, Dammann RH. Frequent promoter hypermethylation of tumor-related genes in head and neck squamous cell carcinoma. Oncol Rep 2009; 22: 1519.

84. Tzao C, Hsu H, Sun G, Lai H, Wang Y, Tung H. Promoter methylation of the $<\mathrm{i}>\mathrm{hMLH1}$ gene and protein expression of human mutL homolog 1 and human mutS 
homolog 2 in resected esophageal squamous cell carcinoma. J Thorac Cardiovasc Surg 2005; 130: 1371.

85. Gonzalez-Ramirez I, Garcia-Cuellar C, Sanchez-Perez Y, Granados-Garcia M. DNA methylation in oral squamous cell carcinoma: molecular mechanisms and clinical implications. Oral Dis 2011; 17: 771-778.

86. Loughran O, Malliri A, Owens D, Gallimore PH, Stanley MA, Ozanne B. Association of CDKN2A/p16INK4A with human head and neck keratinocyte replicative senescence: relationship of dysfunction to immortality and neoplasia. Oncogene 1996; 13: 561-568.

87. Papadimitrakopoulou V, Izzo J, Lippman SM, Lee JS, Fan YH, Clayman G, Ro JY, Hittelman WN, Lotan R, Hong WK, Mao L. Frequent inactivation of p16INK4a in oral premalignant lesions. Oncogene 1997; 14: 1799-1803.

88. Dong Y, Wang J, Dong F, Wang X, Zhang Y. The correlations between alteration of p16 gene and clinicopathological factors and prognosis in squamous cell carcinomas of the buccal mucosa. J Oral Pathol Med 2012; 41: 463-469.

89. Taioli E, Ragin C, Wang XH, Chen J, Langevin SM, Brown AR, Gollin SM, Garte S, Sobol RW. Recurrence in oral and pharyngeal cancer is associated with quantitative MGMT promoter methylation. BMC Cancer 2009; 9: 354.

90. Shaw RJ, Hall GL, Lowe D, Liloglou T, Field JK, Sloan P. The role of pyrosequencing in head and neck cancer epigenetics: correlation of quantitative methylation data with gene expression. Arc Otolaryngol Head Neck Surg 2008; 134: 251-256.

91. Merlo A, Herman JG, Mao L, Lee DJ, Gabrielson E, Burger PC. $5 \mathrm{CpG}$ island methylation is associated with transcriptional silencing of the tumour suppressor p16/ CDKN2/MTS1 in human cancers. Nat Med 1995; 1: 686-692.

92. El-Naggar AK, Lai S, Clayman G, Lee JK, Luna MA, Goepfert H, Batsakis JG. Methylation, a major mechanism of p16/CDKN2 gene inactivation in head and neck squamous carcinoma. Am J Pathol 1997; 151: 1767-1774.

93. Hibi K, Taguchi M, Nakayama H, Takase T, Kasai Y, Ito $\mathrm{K}$. Molecular detection of p16 promoter methylation in the serum of patients with esophageal squamous cell carcinoma. Clin Cancer Res 2001; 7: 3135-3138.

94. Esteller M1 Corn PG, Baylin SB, Herman JG. A gene hypermethylation profile of human cancer. Cancer Res 2001; 61: 3225-3229.

95. Zuo C, Ai L, Ratliff P, Suen JY, Hanna E, Brent TP. O6methylguanine-DNA methyltransferase gene: epigenetic silencing and prognostic value in head and neck squamous cell carcinoma. Cancer Epidemiol Biomarkers Prev 2004; 13: 967-975.

96. Puri SK, Si L, Fan CY, Hanna E. Aberrant promoter hypermethylation of multiple genes in head and neck squamous cell carcinoma. Am J Otolaryngol 2005; 26: 12-17.
97. Lopez M, Aguirre JM, Cuevas N, Anzola M, Videgain J, Aguirregaviria J, Martínez de Pancorbo M. Gene promoter hypermethylation in oral rinses of leukoplakia patients-a diagnostic and/or prognostic tool? Eur J Cancer 2003; 39: 2306-2309.

98. Ai L, Stephenson KK, Ling W, Zuo C, Mukunyadzi P, Suen JY. The p16 (CDKN2a/INK4a) tumor-suppressor gene in head and neck squamous cell carcinoma: a promoter methylation and protein expression study in 100 cases. Mod Pathol 2003; 16: 944.

99. Worsham MJ, Chen KM, Meduri V, Nygren AO, Errami A, Schouten JP, Benninger MS. Epigenetic events of disease progression in head and neck squamous cell carcinoma. Arch Otolaryngol Head Neck Surg 2006; 132: 668-677.

100. Tran TN, Liu Y, Takagi M, Yamaguchi A, Fujii H. Frequent promoter hypermethylation of RASSF1A and p16INK4a and infrequent allelic loss other than 9p21 in betel-associated oral carcinoma in a Vietnamese nonsmoking/non-drinking female population. J Oral Pathol Med 2005; 34: 150-156.

101. Ohta S, Uemura H, Matsui Y, Ishiguro H, Fujinami K, Kondo K, Miyamoto H, Yazawa T, Danenberg K, Danenberg PV, Tohnai I, Kubota Y. Alterations of p16 and p14ARF genes and their 9p21 locus in oral squamous cell carcinoma. Oral Surg Oral Med Oral Pathol Oral Radiol Endod 2009; 107: 81-91.

102. Supia G, Kozomara R, Brankovia-Magia M, Jovia N, Magia Z. Gene hypermethylation in tumor tissue of advanced oral squamous cell carcinoma patients. Oral Oncol 2009; 45: 1051-1057.

103. Pierini S, Jordanov SH, Mitkova AV, Chalakov IJ, Melnicharov MB, Kunev KV. Promoter hypermethylation of CDKN2A, MGMT, MLH1, and DAPK genes in laryngeal squamous cell carcinoma and their associations with clinical profiles of the patients. Head Neck 2014; 36 : 1103-1108.

104. Radhakrishnan R, Kabekkodu S, Satyamoorthy K. DNA hypermethylation as an epigenetic mark for oral cancer diagnosis. J Oral Pathol Med 2011; 40: 665-676.

105. Liu K, Huang H, Mukunyadzi P, Suen JY, Hanna E, Fan C. Promoter hypermethylation: an important epigenetic mechanism for $<\mathrm{i}>\mathrm{hMLH} 1$ gene inactivation in head and neck squamous cell carcinoma. Otolaryngol Head Neck Surg 2002; 126: 548-553.

106. Liu K, Zuo C, Luo QK, Suen JY, Hanna E, Fan C. Promoter hypermethylation and inactivation of hMLH1, a DNA mismatch repair gene, in head and neck squamous cell carcinoma. Diagn Mol Pathol 2003; 12: 50-56.

107. Demokan S, Chuang A, Suoazlu Y, Ulusan M, Yalnaz Z, Califano JA, Dalay N. Promoter methylation and loss of p16(INK4a) gene expression in head and neck cancer. Head Neck 2012; 34: 1470-1475. 


\section{*Correspondence to}

Mario Perez-Sayans

Oral Medicine, Oral Surgery and Implantology Unit

Instituto de Investigacion Sanitaria de Santiago (IDIS)

Spain 